
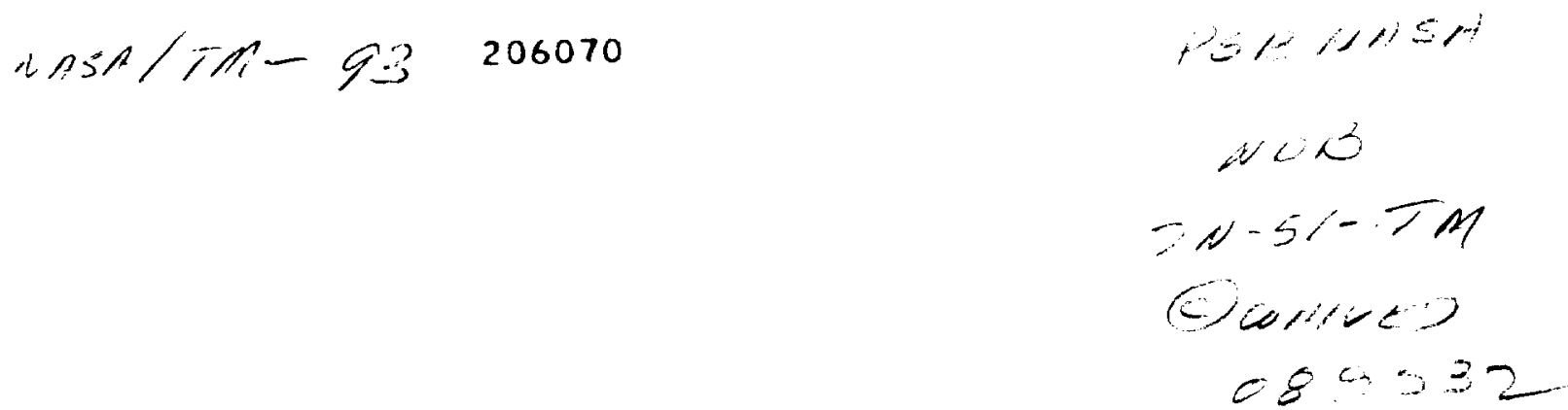

\title{
COMPARISON OF MEMBRANE ATPASES FROM EXTREME HALOPHILES ISOLATED FROM ANCIENT SALT DEPOSITS*
}

\author{
HFLGA STAN-LOTTER',**, MICHAEL SULZNER', EVA EGELSEER', CYNTHIA F. \\ NORTON² and LAWRENCEI. HOCHSTEIN' \\ 1 Insfitufi of Microhiology and Ciencics, University of Vienna. Dr. Bohrg. 9. A-1030 Li'mna. Austria: \\ : Deparmeme of Biology, Lniversity of Maine at Augusta, Maine 04330. U.S.A.: 'NASA Ames Research \\ Center. Moffent Field. California 94035 , U.S.A.
}

(Received 6 August, 1992)

\begin{abstract}
Hahophilic microorganisms were isolated from Triassic and Permian salt deposits. Two were rods and grew as red colonies; another was a coccus and produced pink colonies. The rods lysed in solutions that lacked added sodium chloride. Growth of all isolates was inhibited by aphidicolin and their bulk proteins were acidic as judged from isoelectric focusing. Therefore, these organisms were tentatively identified as extreme halophiles. Whole cell proteins patterns of the isolates following gel electrophoresis were distinct and differed from those of representative type strains of halophilic bacteria. The membrane ATPases from the rods were similar to the enzyme from Halobacterium saccharororum with respect to subunit composition, enzymatic properties and immunological cross-reaction, but differed slightly in amino acid composition. If the age of the microbial isolated is similar to that of the salt deposits, they can be considered repositories of molecular information of great evolutionary interest.
\end{abstract}

\section{Introduction}

Salt deposits which resulted from evaporation of sea water, particularly during the Triassic and Permian periods, are found throughout the world. The maps published by Zharkov (1981), which were constructed taking continental drift into consideration, show a large arid climatic zone. where present-day England, the Zechstein regions of Northern Germany and the alpine region were close to the equator. This zone contained all early and late Permian evaporitic basins. Microscopic studies reveal the presence of bacteria in thin sections or in residues of dissolved rock salt (Rippel 1935 and other literature cited by Sonnenfeld, 1984). Cultivation of viable bacteria from rock salt of Permian age (Zechstein) was reported by Reiser and Tasch (1960) and by Dombrowski (1963), although Bien and Schwartz (1965) were unable to confirm these results.

Recently, extrcmely halophilic bacteria were isolated from salt crystals from an English salt mine (Norton 1988, 1989) whose deposition appears to have occurred during the Triassic period (Arthurton 1973). Extreme halophiles have also been

* Presented at the Session 'Water in the Solar System and lis Role in Exobiology' during the 26th General Assembly of the Europein Geophysical Society. 22-26 April 1991 in Wiesbaden. Germany.

** Cirrenponding atuthor. 
isolated from a Permian age bedded salt deposit located in New Mexico (R. Vreeland, personal communication) and from rock salt from an Austrian salt mine near Bad Ischl, as will be described in this communication.

The extreme halophiles are members of the archaebacteria (recently renamed Archaca; Woese et al., 1990) which consist of organisms throught to have diverged early from the main line of prokaryotic evolution (Woese and Fox, 1977). Ribosomal RNA sequence comparisons suggest a slow rate of evolution for archaebacteria (Woese, 1987). Their cellular components could thus represent a repository of information with respect to the early evolution of life. The presence of microorganisms in salt crystals of great antiquity offers considerable promise, particularly if the in situ age of such organisms can be established.

The $F_{1} F_{0}$ ATP synthases (F-type ATPases) catalyze the synthesis of ATP at the expense of a proton gradient either via respiration or photosynthetically (for a recent review see Fillingame, 1990). The ubiquitousness of the enzyme implies an early origin during the evolution of life. However, the enzyme's structural and functional complexity suggests its development during a long evolutionary process. The membrane ATPase from the extreme halophile Halobacterium saccharovorum has been intensely studied by us (Kristjansson and Hochstein 1985; Hochstein et al., 1987; Stan-Lotter and Hochstein, 1989; Stan-Lotter et al., 1991) with the notion that it might provide information with respect to the evolution of F-type ATPases. A comparison between membrane ATPases from $H$. saccharovorum with those of bacterial isolates from rock salt is described here. In addition, the microbial isolates from rock salt were compared in several experiments with halobacterial type strains obtained from culture collections.

\section{Material and Methods}

\section{BACTERIAL STRAINS}

H. saccharovorum (ATCC 29252) was the original strain isolated from a solar evaporation pond located in the San Francisco Bay area (Tomlinson and Hochstein, 1976). Other extreme halophiles were obtained from the German Collection of Microorganisms (DSM), Braunschweig. Bacterial isolates from salt sediments were from two locations, the Winsford salt mine in Cheshire, England, and the salt mine (Salzberg) near Bad Ischl, Austria. Samples (ca. $0.5 \mathrm{~g}$ ) from the Winsford mine were collected after blasting from newly exposed faces and kept in absolute ethanol for transport. After $6 \mathrm{~h}$, the salt pieces were transferred to $10 \mathrm{ml}$ of sterile complex medium that was $20 \%$ with respect to $\mathrm{NaCl}$ (Norton and Grant, 1988). Samples of rock salt, with varying contents of clay, were obtained from the salt mine at Bad Ischl. Sample pieces of about $2 \mathrm{~g}$ were dipped in ethanol and flamed. They were transferred to $50 \mathrm{ml}$ of a similar culture broth (M2 medium; Tomlinson and Hochstein 1972) and incubated at $37^{\circ} \mathrm{C}$ with shaking. After three to four wecks, the Winsford samp's became turbid, indicating growth of microorganisms, 
and loopfuls of the cultures were streaked on agar plates. The Bad Ischl rock salt caused turbidity of the medium upon dissolution, due to its clay content. Plates were steaked with those cultures following 4 weeks of shaking at $37^{\circ} \mathrm{C}$. Colonies appeared on the plates after 7-10 days (Winsford samples) and three to five weeks (Bad Ischl samples), respectively, and were purified further by repeated spreading on solid M2 medium.

\section{ANTIBIOTIC SENSITIVITY}

Antibiotic sensitivity was determined using discs that contained $10 \mu \mathrm{g}$ of antibiotic/ disc in agar plates with $M 2$ medium. Antibiotics were from Sigma Chemical company.

\section{POLyaCRYLAMIDE GEL ELECTROPHORESIS OF BACTERIAL PROTEINS}

Cells from the late log or early stationary phase were lysed either in distilled water or boiled for $5 \mathrm{~min}$ with $2 \%$ sodium dodecyl sulfate (SDS). Polyacrylamide gel electrophoresis, isoclectric focusing and staining with Coomassic Blue or silver was performed as described previously (Stan-Lotter e't al., 1989). Ampholytes were from Pharmacia.

\section{PRLPARATION AND ASSAYS OF MEMBRANES AND ATPASE}

Membranes and the ATPases from $H$. saccharovorum and strain $54 \mathrm{R}$ were prepared as described carlier (Stan-Lotter et al., 1991). For the preparation of small amounts of membranes, cells were sonicated for $3 \times 1$ min with a Branson sonifier, set at 55. The membranes were obtained by centrifuging the sonicated suspension for $1 \mathrm{~h}$ in a Beckman TL-100 rotor at $65000 \mathrm{rpm}$. ATPase activity was measured as described previously (Kristjansson and Hochstein 1985). The molecular mass of the ATPase was determined by gel filtration on a Sephacryl S-300 column (2.7 $\times 95 \mathrm{~cm})$, which was equilibrated in $0.8 \mathrm{M}\left(\mathrm{NH}_{4}\right)_{2} \mathrm{SO}_{4}, 50 \mathrm{mM}$ Tris- $\mathrm{HCl}, \mathrm{pH} 8.0$. S- 300 and gel filtration standards were from Pharmacia.

IMMLNOLOGICAL ASSAY [WESTERN BLOT]

The immunoblot procedure was carricd out as described (Harlow and Lane, 1988) and the immunoconjugates were visualized with alkaline phosphatase. Polychonal rabbit antiserum against subunit $A$ of the vacuolar ATPase was a gift of Dr. E.J. Bowman.

\section{OIHER MITHOUS}

Protein was determined by the method of Bradford (1986) or lowry et al. (1951) with bovine serum albumin as standard. Amino acid composition was determined with a Waters HPLC (Picotag) system, following hydrolysis of enzyme with $6 \mathrm{~N}$ $\mathrm{HCI}$ at $110^{\circ} \mathrm{C}$ for $20 \mathrm{hr}$. Lipids were analysed by thin layer chromatography according to Ross at al. (1981, 1985). 


\section{Results}

Properties of extremely halophiLic isolates from SALt SEDIMENTS

A number of pigmented and non-pigmented colony types were isolated from rock salt on agar plates. Several pigmented colonies were picked for further study. Strains $54 \mathrm{R}$ and Blr were red, whereas strain Blp was pink. Phase contrast microscopy of $54 \mathrm{R}$ and Blr revealed short motile rods; Blp was a coccus growing in clusters. In the absence of salt, most halophilic archeabacteria lyse (Staley et al., 1989). This was also observed with strains $54 \mathrm{R}$ and Blr, when they were placed in distilled water, but not with strain Blp, as is true for other halococci (Staley et al., 1989).

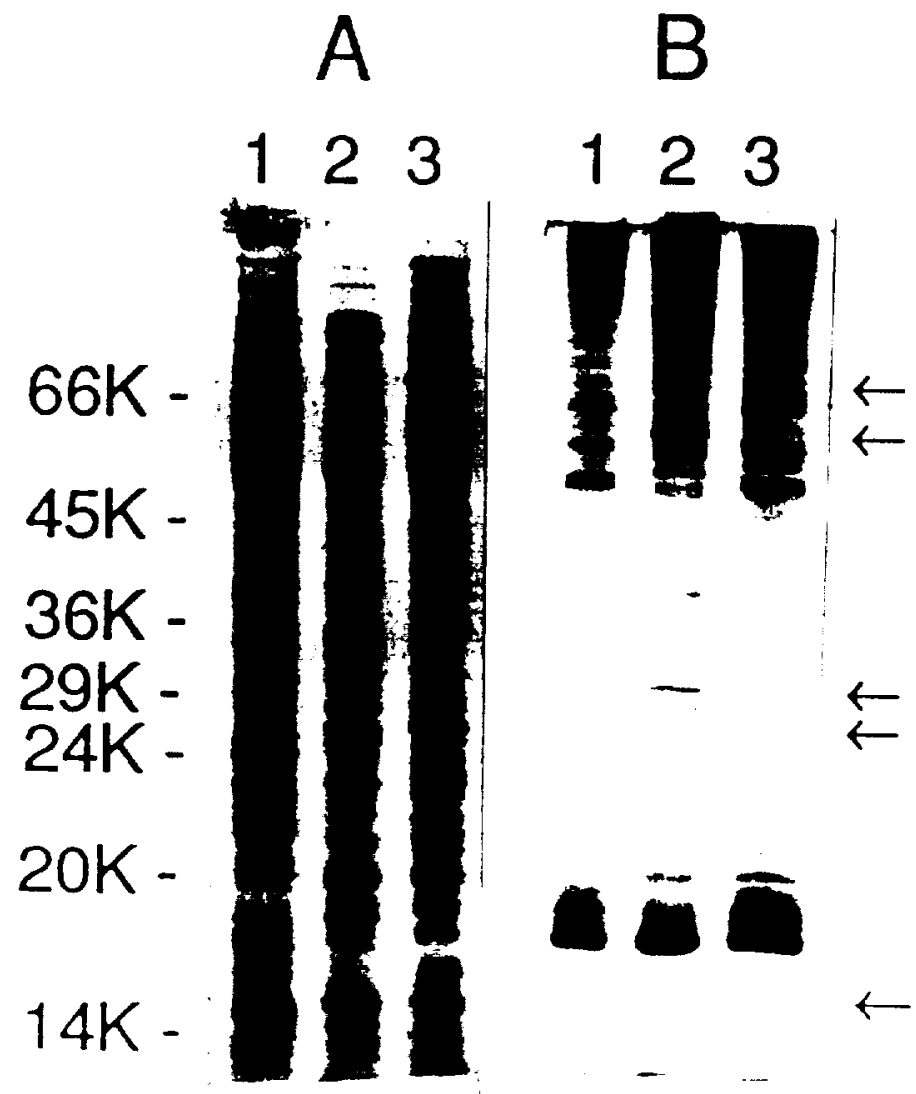

Fig. 1. SDS polyacrylamide gel electrophoresis of total cell proteins from strain Blr (lane 1), strain Blp (lane 2) and $H$. saccharovorum (lane 3). Acrylamide concentration was $12 \%$. Protein concentration was ca. 40kg. Gels were stained with Coomassic Blue (panel $A$ ) or silver (pancl B). Molecular mass markers are indicated on the left. Arrows point to proteins which stained well with Coomassic Blue. but only ueakly with silver. 
We previously observed that SDS polyacrylamide gel electrophoretograms of total cell proteins from extremely halophilic bacteria are distinctive at the species level (manuscript in preparation). Therefore, we compared the patterns of total cell proteins from strains Blr, Blp and $54 \mathrm{R}$ with those of other extreme halophiles. Figure I shows the results of such an experiment. Proteins were either stained with Coomassic Blue (panel A) or with silver (panel B). Both staining methods gave distinct patterns. Several proteins, which stained well with Coomassie Blue, poorly bound the silver stain (indicated by arrows in Figure 1). This behaviour

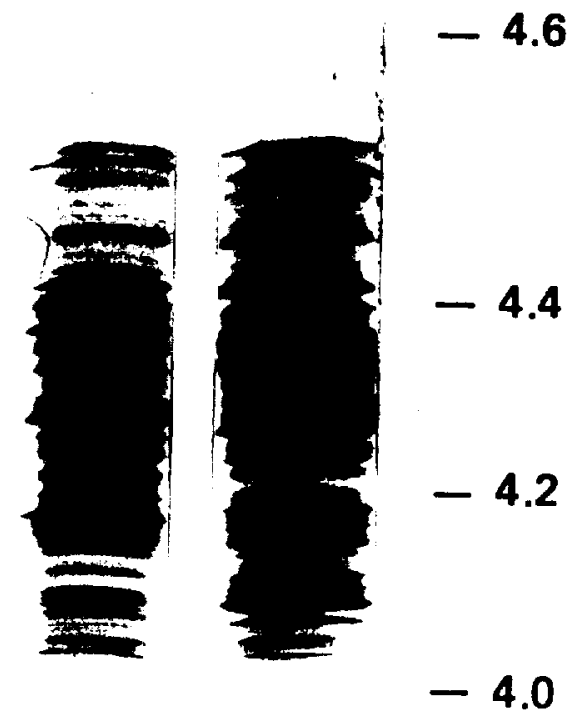

$-4.0$
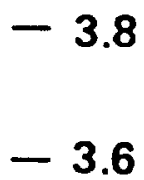

Fig. 2. Isoelectric focusing of total cell proteins from $H$. saccharovorum (lane 1) and strain $54 \mathrm{R}$ (lane 2). The approximate pHe gradient is indicated to the right. (iels were stained with Coomassie Blue. Protein concentrations were $51 \mu \mathrm{g}$ (lane 1 ) and $55 \mu \mathrm{g}$ (latne 2). 
could reflect a very low content of cysteine in some halobacterial proteins (StanLotter $e t$ al., 1989). The protein pattern from stain Blr resembled that of $H$. saccharovorum (Figure 1, lanes 1 and 3 ) and was different from those of the following other archaebacterial species: $H$. vallismortis, Haloferax mediterranei, H. halobium. $H$. denitrificans, Natronobacterium pharaonis and $N$. gregoryi (not shown). The total cell protein pattern of strain Blp (Figure 1, lane 2) was different from those of Halococcus morrhuae and Natronococcus occultus (not shown).

The bulk proteins of halobacteria have an excess of acidic over basic amino acids (Reistad 1970) which is evident when visualizing them on isoelectric focusing gels in the appropriate $\mathrm{pH}$ ranges (Stan-Lotter et al., 1989). Following isoelectric focusing in the presence of $8 \mathrm{M}$ urea and nonionic detergent, the protein patterns of lysed cells of $H$. saccharovorum (Figure 2, lane 1) and strain $54 \mathrm{R}$ (Figure 2, lane 2) were similar. Both strains possessed mainly acidic proteins, with isoelectric points between 4 and 4.5 . Several major bands of strain $54 \mathrm{R}$ migrated closer to the anode than comparable bands from $H$. saccharov'orum. The bulk proteins from strains Blr and Blp were also acidic, with isoelectric points in the range of 3.8 to 4.5 (data not shown).

Halophilic archaebacteria are typically sensitive to aphidicolin, an inhibitor of eukaryotic DNA polymerases (Schinzel and Burger, 1984). In addition, these organisms are inhibited by baccitracin and novobiocin, but not by ampicillin, nalidixic acid or low concentrations of chloramphenicol. Table I shows the sensitivity of halobacterial strains to several antibiotics. For comparison, the response of the eubacterium Escherichia coli to the same antibiotics is also given. These results were in general consistent with previous studies of antibiotic sensitivities of archaebacteria (Hilpert et al, 1981).

With strain $54 \mathrm{R}$, lipid analysis (Ross et al., 1981, 1985) had been performed (Norton 1988), which had indicated the typical ether-bond containing lipids of archaebacteria.

\section{COMPARISON OF ATPASES}

Membrane ATPases from $H$. saccharovorum and strain $54 \mathrm{R}$ were solubilized by detergents and purified by several chromatographic steps (see references given in Methods). Figure 3 shows an SDS gel of the purified enzymes. The two major subunits of the ATPase from strain $54 \mathrm{R}$ (lane 2) appeared identical to subunits $I$ and II from $H$. saccharovorum (lane 1) with respect to molccular masses ( $87 \mathrm{kDa}$ and $60 \mathrm{kDa}$, respectively). Some minor protein bands were also visible, but their significance is not clear at present.

The membrane-bound ATPase from Sulfolobus acidocaldarius resembles the vacuolar ATPase from the endomembrane system of eukaryotes, and it has been suggested that generally the archaebacterial ATPases are closely related to the ATPases from vacuoles (Gogarten et al., 1989). There is increasing evidence that this is the case for the ATPases from the extreme halophiles. A strong immunological crossreaction between subunit I of the ATPase from $H$. saccharovorum and subunit 


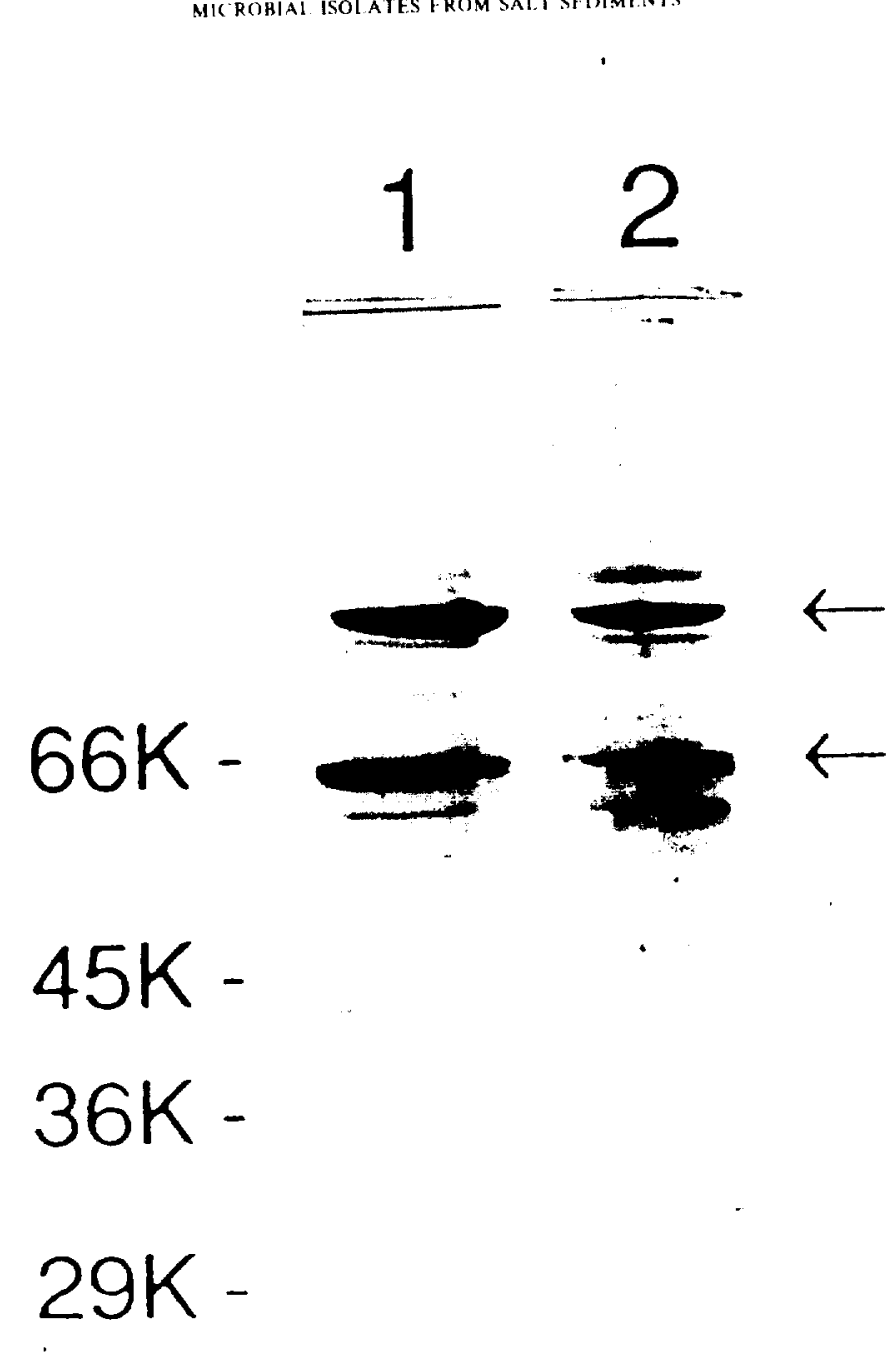

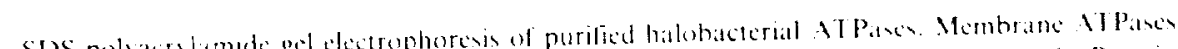

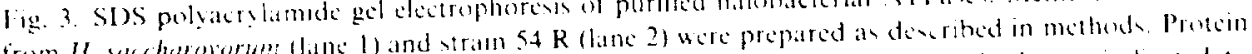

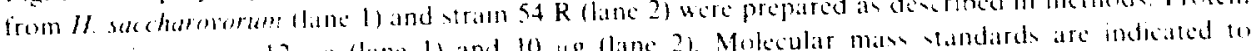

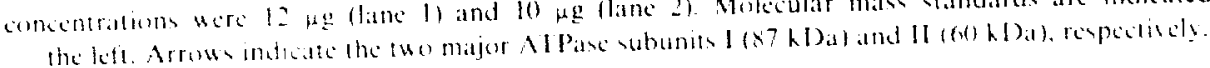

A from the vacuolar ATPase of Neurospora crassa was recently reported (Stanlotter et al., 1991). As shown in Figure 4, the antiserum against subunit A from the ATPase of $N$. crassa, which recognized subunit 1 from $H$. saccharovorm (lane 1), also reacted with proteins of similar sizes in membranes from strains $54 \mathrm{R}$ (lane 2) and Blr (lane 3). Two additional distinct faster migrating proteins in all three samples reacted with the antiserum. These bands represented contaminating cytoplasmic proteins as was confirmed in a separate immunoblot using cytoplasm 


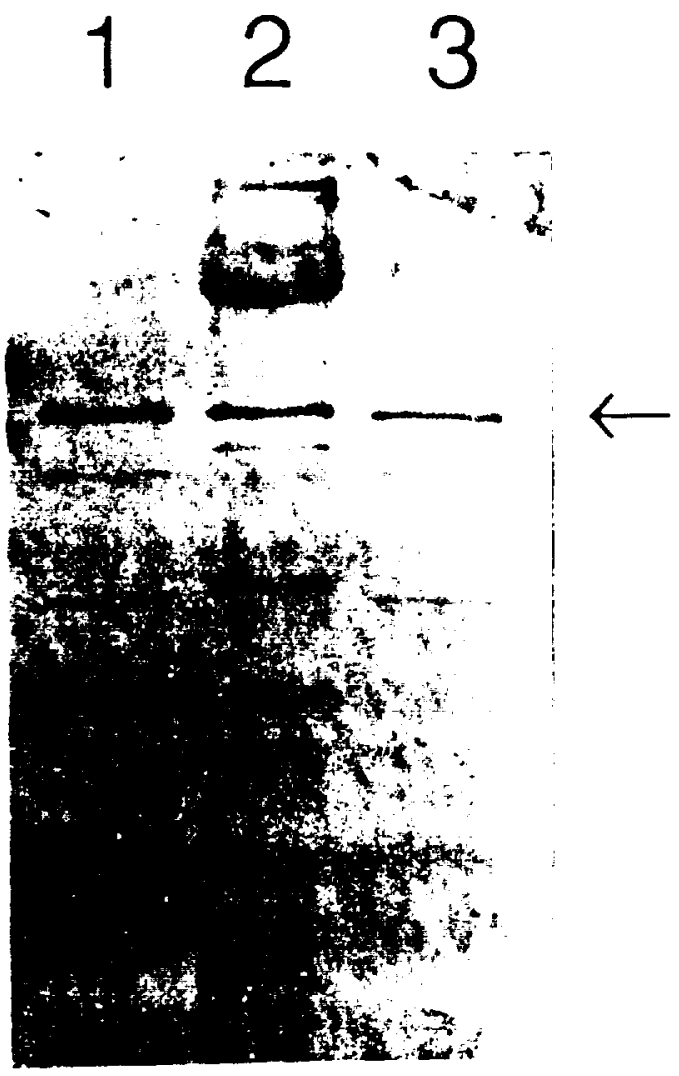

Fig. 4. Immunoreactivity of halobacterial membranes with an antiserum to subunit $A$ from the vacuolar ATPase of Nourospora cross. Immunobloting was performed with polyctonal rabhit antiserum and

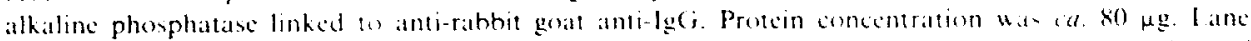

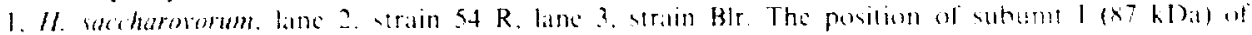
the halobackerial Al Panc is marked by the arrou.

from $H$. saccharovorum (data not shown). In strain $54 \mathrm{R}$ a broad band of about $200 \mathrm{kDa}$ also crossreacted with the antiserum (lane 2).

The amino acid compositions of the enzymes from strain $54 \mathrm{R}$ and $H$. saceharovorum are shown in Table II. The ATPase from $54 \mathrm{R}$ possessed a slightly lower content of Gly and Lys, and a higher content of Arg and acidic amino acids. Isoclectric focusing of the major subunits indicated identical isoclectric points of subunits I from both enzymes, but a slightly more acidic isoelectric point for subunit Il of strain $54 \mathrm{R}$ (not shown). This might contribute to the overall small increase in the excess of acidic amino acids for the ATPase from this strain. Other properties of the ATPases from $H$. saccharovorum and strain $54 \mathrm{R}$ are summarized in Table III. 
MICROBIN ISOLAMLIROM SAI I SI HMINIS

TABLE I

Fflect of antibiotics on the grow th of halophilic isolates

\begin{tabular}{|c|c|c|c|c|c|}
\hline \multirow[b]{2}{*}{ Sntibiotic } & \multicolumn{5}{|c|}{ Microorganisms } \\
\hline & Hh. sarih. & $54 \mathrm{R}$ & $\mathrm{Blr}$ & $\mathrm{BIp}$ & Ecoli \\
\hline Aphidicolin & 14 & 15 & 10 & 17 & - \\
\hline Bacitracin & 6 & 7 & 8 & 13 & 15 \\
\hline Nonobiocin & 45 & 46 & 42 & 50 & 10 \\
\hline Nalidiac acid & - & - & - & - & 16 \\
\hline Ampicillin & - & - & - & - & 19 \\
\hline Chloramphenicol & - & - & - & - & 18 \\
\hline
\end{tabular}

Tonn of inhibition in millimeters:-, no inhibition.

TABI_E II

Amino acid composition of the purified ATPases from $H$, sacharoworum and strain $54 \mathrm{R}$

\begin{tabular}{|c|c|c|}
\hline \multirow{2}{*}{$\begin{array}{l}\text { Amino } \\
\text { acid }\end{array}$} & \multicolumn{2}{|l|}{ Mol } \\
\hline & 11. saceh. & $54 \mathrm{R}$ \\
\hline Asp & 11.6 & 12.8 \\
\hline Cilu & 11.6 & 12.7 \\
\hline Ser & 4.6 & 4.1 \\
\hline Gly & 10.7 & 8.6 \\
\hline His & 1.9 & 2.5 \\
\hline Arg & 4.9 & 5.9 \\
\hline Tht & 5.0 & 7.1 \\
\hline Ala & 14.3 & 14.9 \\
\hline Pro & 4.3 & 3.8 \\
\hline Tyr & 1.6 & 1.4 \\
\hline Val & 8.6 & 8.2 \\
\hline Met & 1.4 & 0.6 \\
\hline Cys & n.d." & n.d.: \\
\hline I.lc & 4.8 & 4.7 \\
\hline Leu & 7.8 & 7.9 \\
\hline Phic & 31 & 2.9 \\
\hline $1 . \mathrm{n}$ & 3.1 & 2.0 \\
\hline Trp & n.d.: & n.d.: \\
\hline
\end{tabular}

s. n.d., not determined.

The relative molecular masses of the native enzymes were essentially identical. although the value for the ATPase from $H$. saccharovorum was considerably higher than previously reported (Hochstein $\mathrm{et}$ al., 1987). This was related to the method of determination which was carried out in the presence of $0.8 \mathrm{M}\left(\mathrm{NH}_{4}\right)_{2} \mathrm{SO}_{4}$ instead of $4 \mathrm{M} \mathrm{NaCl}$. The presence of high concentrations of salt can cause retarded elution of proteins from certain gel matrices. The two enzymes were activated by detergents and inactivated by nitrate. Both enzymes had relatively alkaline pH optima, unlike 
TABI.F III

Some propertion of the ATPisce from /f. wa charoverum and strain $54 \mathrm{R}$

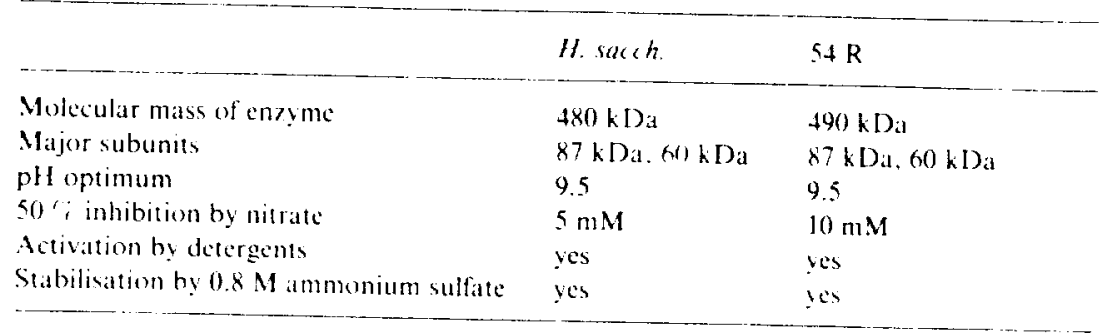

the ATPase from H. halobium (Nanba and Mukohata 1987), and were stable for several months in the presence of $0.8 \mathrm{M}\left(\mathrm{NH}_{4}\right)_{2} \mathrm{SO}_{4}$. We have been unable to identify a membrane ATPase in strain Blp, when using the procedures described in the Method section.

\section{Discussion}

Two of the distinct morphological types of bacteria from salt sediments of paleozoic origin were studied here. One consisted of rods ( $\mathrm{B} / \mathrm{r}$ and $54 \mathrm{R}$ ) and resembled H. sacharovorum as judged by clectrophoretograms of total cell proteins (Figures 1 and 2) and lipid analysis in the case of strain $54 \mathrm{R}$ (Norton 1988). The other type wals a coccus $(B \mid p)$. which did not show protein patterns resembling those of any halophilic archacbacteria, but whose sensitivity to antibiotics suggested it was an archatebacterium (table I). The ATPase of strain $54 \mathrm{R}$ showed a higher content of acidic amino acids and a slightly lower isoclectric point for subunit II than the ATPase of $H$. sacharovorum. This could reflect amino acid substitutions and will be investigated further by sequencing of the ATPase subunits. Interestingly, several of the heavier bands of total cell protein from strain $54 \mathrm{R}$ appeared also slightly more acidic than their presumable counterparts in $/ 1$. saccharovorum (Figure 2). Sequences of several archachacterial ATPases are now known: very recently, the sequences of the two major subunits of the ATPase from another halophilic archacbacterium. H. halohium, were published (lhara and Mukohata 1991).

While the isolation and characterization of halophilic bacteria from salt sediments does not present any unusual problems, establishing the age of these organisms is another matter. There is little question as to the age of the deposits, per se. In the case of the Austrian salt sediments, analysis of pollen from extinct coniferes and other plants as well as sulfur isotope dating were used (Klaus, 1974, Pak and Schauberger. 1981). Values obtained with either method pointed to a Permian origin of the salt deposits and correlated well. Pollen in rock salt are usually well preserved as judged from the microscopic appearance of their fine structures such as air sacs and surface ridges (Klaus, 1987). It seems that these rather delicate structures either did not experience grat temperatures and pressures, or that they tolerated them 
Well while being embedded within the salt. By extension, this leads to the conclusion that microorganisms in the same sediments also may not have experienced great stresses.

Reports of recovery of viable halophilic bacteria from crystallized brine support the view that evaporation is not destruclive for these cells. Survival of halophilic archatcbacteria for at least 6 months in fuid inclusions od salt crystals was found by Norton and Grant (1988). Viability of halophilic bacteria of up to five vears of storage in salt crystals has been described by Eimhjellen (1965). It thus appears that the crystal environment is protective rather than hostile. What remains unproven is the age of the individual microbial cells that are located within the primary crystals from salt deposits, and from which these and similar cultures were derived. Inventigations to clarify these issues are in progress. However. since salt erystals offer an enviromment conducive for the survival of microorganisms or their cellular comstituents, such organisms might be a potential source of evolutionary information. Furblermore, the presence of such organisms could be taken as incentive to look for life forms, cither past or present. in extraterrestrial sediment enviromments. such as on Mars.

\section{Acknowledgments}

We thank Dr. W. Lubitz. University of Vienna, for laboratory space: Dr. E. J. Bowman. University of California, for a gift of anti-vacuolar ATPese antiserum: Dr. R. Zetter. Inniversity of Vienna, for helpful discussions, Mr. E. Denner. University of Vienna. for microncupic examinations and the Österreichische Salinen AG for valuable information. This work was partially supported by SETI Cooperative Agrement NCC2-578 to HS and funds from the NASA Exobiology Program to L.1H. MS was supported by the Austrian Ministry of Science and Research. CFN hanks Dr. W. D. Grant. University of Leicester. UK, with whose support and collaboration the Cheshire isolations were carried out.

\section{References}

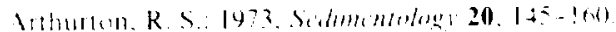

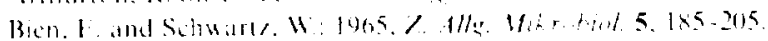

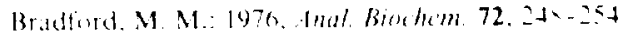

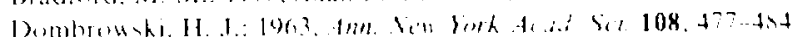

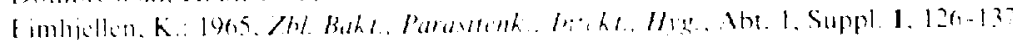

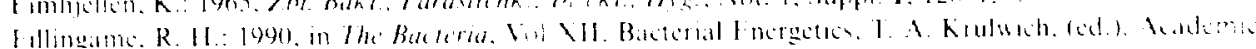
Pres. Sin I liggon.

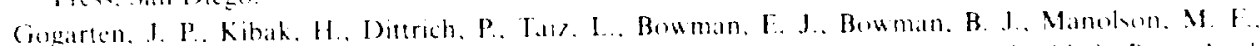

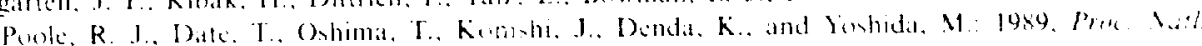
Acad. Sit. U.S.A. 86, 6601-6665.

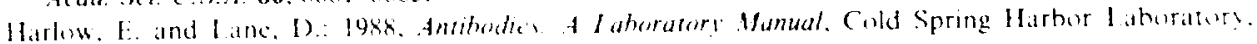
New York.

Hilpert. R. Winter. I. Hammes, W., and Kandler. O.: 1981, Zht. Baht. Hag. I. Alh. Orig. C $2.11-$ 20 . 
Hochstein, L. I., Kristjansson, H. and Altekar, W.: 1987, Biochem. Biophys. Re's. Commun. 147, 295300 .

Thatsa, K. and Mukohata, Y.: 1991, Arch. Biochem. Biophlys 286, 111-116.

Klaus. W.: 1974, Carinthia $I$, 164/Jahrg. 84, 79-85, Klagenfurt.

K'aus, W.: 1987, Finführung in die Paläobotonik, Band I. F. Deuticke Verlag. Vienna.

Kristjansson, H. and Hochstein, L. I.: 1985, Arch. Bioche'm. Biophys. 241, 590-595.

Lowry, O. H., Rusebrough, N. J., Farr, A. L., and Randall. R. 1.: 1951, J. Biol. Chem. 193. 265275 .

Ninba, T. and Mukohata, Y.: 1987. J. Bioch'm. 102, 591-598.

Norton, C. IF and Grant, W. D.: 1988, J. Cien. Microbiol. 134, 1365-1373.

Niorton, C. F.: 1988, Abstr, 1-84, Annu. Meetg. Am. Soc. Microbiol., Am. Soc. Microbiol.. Washington.

Norton. C. F.: 1989. Abstr. I-108. Annu. Meetg. Am. Soc. Microbiol., Am. Soc. Microbiol. Washington. Pak. F. and Schatuberger, O.: 1981, Lirh. Cieol. B.-A., Jahrg. 1981, 185-192.

Reiser, R. and Tanch, P.:: 1960. Trams. Kansas Acad. Sci. 60, 31-34.

Reistad, R.: 1970, Arch. Mikrobiol. 71. 353-360.

Rippel. A.: 1935, Arch Mikrohiol 6. 350-35k.

Ross. 11. N. M. Collins, M. D.. Tindall, B. J., and Grant, W. D.: 1981, J. Gen. Mficrehiol. 123. 7580.

Ross, H. N. M., Grant, W. D.. and Harris, J. E.: 1985, in Chemical Methods in Bacterial Sistematics. Goodfellow, M. and Minnekin. D, E... (eds.), Acad. Press, London, New York

Schinzel, R. and Burger, K. J.: 1984, FEMS Microhiol. Lett 25, 187-190.

Sonnenfeld, P.: 1984, Rrines and Fraporites, Academic Press. Orlando, Florida

Staley, J. T., Bryant, M. P., Pfennig. N., and Holt, J. G.: 1989, Berger's Manual of Sy stemath Bacteriolegy'. Vol. 3. Willams and Wilkins. Baltimore.

Stan-Lotter, H., and Hochstein, L. I.: 1989, Eur. J. Biochem. 179, 155-160.

Stan-Lotter, H., Lang. F. J. Jr., and Hochstein. L. I.: 1989, Appl. Theoret. Electroph. 1, 147-153.

Stan-Lotter. H., Bowman. E. J., and Hochstein. L. I.: 1991, Arch. Biochem. Biophys. 284. 116-119.

Tumlinson. G. A. and Hochstein. L. 1.: 1972, Can. J. Microbiol. 18.698-701.

Tomlinson. G. A. and Hochslein. L. I.: 1976. Can I. Microhiol. 22. 587-591.

Wisese. C. R.: 1987, Microhiol Riv. 51, 221-271.

Wiocse. C. R. and Fox, G. E.: 1977. Proc: Nath Acad. Sci. L.S.A. 74, 5088-5090.

Woese. C. R., Kandler, O., and Wheclis, M. L.: 1990, Proc. Nat. Acad. Sci. C.S. A. 87, 45:6-4579.

Zharkov, M. A.: 1981. Histor of Paleozoic Salt Accumule:ton, Springer Verlag, Berlin. Heidelberg. New York. 